\title{
CORRIGENDUM
}

\section{City Networks as Alternative Geographies of Southeast Asia - CORRIGENDUM}

\section{Tim Bunnell}

doi: 10.1017/trn.2012.2, Published by Cambridge University Press,

18 March 2013.

The abstract of the above publication (Bunnell 2013) was originally published with a punctuation error. A semi-colon in line 21 should have been a comma. The corrected sentence is reproduced below:

In the second section of the paper, I consider three types of regional formations that have been identified in research on globalisation: the global triad regions, region states, and inter-Asia flows of capital, models and people which I examine do not map onto conventional cartographies of Southeast Asia.

The editors apologise for any misunderstanding this caused.

\section{Reference}

Bunnell, Tim. 2012. City Networks as Alternative Geographies of Southeast Asia. TransRegional and -National Studies of Southeast Asia 1(1), 27-43. doi:10.1017/ $\operatorname{trn} .2012 .2$ 